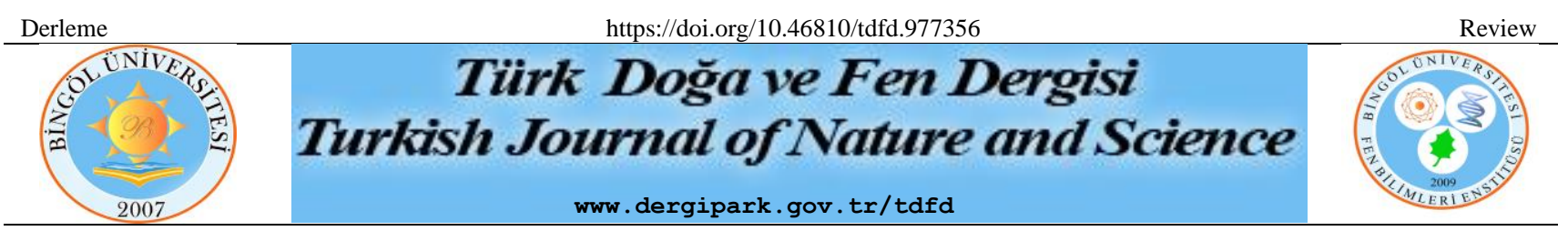

\title{
Nörodejeneratif Hastalıkların Tedavisinde Nöroprotektif Ajan Olarak Tıbbi Bitkiler ve Fitokimyasallar
}

\author{
Sevgi GEZİCi ${ }^{1 *}$, Didem KOÇUM ${ }^{2}$ \\ ${ }^{1}$ Gaziantep Üniversitesi, Tıp Fakültesi, Temel Tıp Bilimleri, Tıbbi Biyoloji Anabilim Dalı, Gaziantep Türkiye \\ ${ }^{2}$ Kilis 7 Aralık Üniversitesi, Fen-Edebiyat Fakültesi, Moleküler Biyoloji ve Genetik Bölümü, Kilis, Türkiye \\ Sevgi GEZİCI ORCID No: 0000-0002-4856-0221 \\ Didem KOÇUM ORCID No: 0000-0003-2519-0608
}

*Sorumlu yazar: sevgigezici@gantep.edu.tr

(Alınış: 01.08.2021, Kabul: 29.09.2021, Online Yayınlanma: 31.12.2021)

\begin{abstract}
Anahtar
Kelimeler

Nörodejeneratif

bozukluklar,

Tibbi bitkiler,

Tamamlayıcı tıp,

Nöroprotektif,

Geleneksel tıp

Öz: Nörodejeneratif hastalıklar, sinir hücrelerindeki yapısal ve işlevsel dejenerasyon ve/veya sinir hücrelerinin ölümü ile karakterize multifaktöryel hastalıklardır. Alzheimer, Parkinson, Huntington, Amyotrofik Lateral Skleroz ve Multiple Skleroz insanların yaşam kalitesini olumsuz yönde etkileyen ve hızlı ilerleme yeteneğinde olan en önemli nörodejeneratif hastalıklardır. Nörodejeneratif hastalıkların kesin bir tedavisi henüz bulunmamakla birlikte; hastalığın seyrini yavaşlatarak insanların yaşam kalitelerini artırmayı hedefleyen tedavi yaklaşımları uygulanmaktadır. Mevcut terapötik müdahaleler ve bu doğrultuda kullanılan ilaçların, kronik kullanımda ciddi yan etkiler meydana getirmiş olması, uygulanan tedavi stratejilerinde karşılaşılan en önemli güçlükler arasında olup; bu durum hastaların geleneksel tıp uygulamalarına yönelmesine neden olmuştur. Bu bağlamda, nörodejenerasyonda beyin hasarlarının iyileşmesine katkıda bulunan ve yeni sinaps oluşumlarını teşvik ederek öğrenme ve hafıza fonksiyonlarını artırıcı yönde potansiyele sahip olan nöroprotektif özellikteki tıbbi bitkilerle yapılan tamamlayıcı tıp uygulamaları günümüzde önemli bir yaklaşım haline gelmiştir. Tıbbi bitkiler; ihtiva ettikleri fitokimyasallar sayesinde, nörodejeneratif hastalık gelişimi ile ilişkili hücresel ve moleküler mekanizmalarda etkili olarak, hastalığın prognozunu yavaşlatmaya ciddi anlamda katk1 sağlamaktadır. Bu derlemede, nörodejeneratif hastalıkların mekanizmaları ve bu hastalıkların tedavisinde terapötik ajan olarak kullanılma potansiyeline sahip olan nöroprotektif tıbbi bitkiler ve fitokimyasallar kaleme alınmıştır.
\end{abstract}

\section{Medicinal Plants and Phytochemicals as Neuroprotective Agents in the Treatment of Neurodegenerative Diseases}

Keywords
Neurodegenerative
disorders,
Medicinal plants,
Complementary
medicine,
Neuroprotective,
Traditional
medicine

\section{Keywords}

disorders,

Medicinal plants,

Complementary

Neuroprotective, medicine

\begin{abstract}
Neurodegenerative diseases are multifactorial diseases characterized by structural and functional degeneration and/or death of nerve cells. Alzheimer's, Parkinson's, Huntington's, Amyotrophic Lateral Sclerosis and Multiple Sclerosis are the most important neurodegenerative diseases that negatively affect people's quality of life and can progress rapidly. Although there has been no definitive treatment for neurodegenerative diseases, yet; treatment approaches aiming to increase the people's quality of life by slowing the course of the disease are applied. The existing therapeutic interventions and the drugs used in this direction, causing serious side effects in chronic use, are among the most important difficulties encountered in the applied treatment strategies; which has caused patients to turn to traditional medicine practices. In this context, complementary medicine applications with neuroprotective medicinal plants, which contribute to the recovery of brain damage in neurodegeneration and have the potential to increase learning and memory functions by promoting the formation of new synapses, have become an important approach today. Thanks to the phytochemicals, medicinal plants contribute significantly to reduce the prognosis of the disease by effective in the cellular and molecular mechanisms associated with the development of neurodegenerative disease. The mechanisms of neurodegenerative diseases and neuroprotective medicinal plants and phytochemicals that have the potential to be used as therapeutic agents in the treatment of these diseases are summarized in this review.
\end{abstract}




\section{GíRiş}

Antik çağlardan bu yana, insanoğlu pek çok hastalığın şifasını doğada aramıştır. Bu nedenle, tedavi amacıyla bitkilerin kullanılması milattan önceki çağlara kadar uzanmaktadır. Günümüzde, dünya genelinde olduğu gibi, ülkemizde de bütünleyici ve tamamlayıcı tıp alanında bitkiler ve bitkilerden elde edilen doğal bileşikler çoğu hastalığın tedavisinde tercih edilmekte ve her geçen gün kullanımlarına yönelik ilgi ve talep artmaktadır [1, 2, 3]. Dünya Sağlık Örgütü (WHO) tarafından yapılan bir araştırmada; dünya üzerinde pek çok hastalığın tedavisinde halkın ilk başvurduğu tedavi yönteminin bitkisel kaynaklı olduğu ortaya konulmuştur $[4,5]$. Bununla birlikte, dünya geneline bakıldığında reçeteyle satılan ilaç içeriklerinin yaklaşık \%25'lik kısmının bitkisel kaynaklı etken maddelerden oluştuğu da belirtilmiştir. Antitümör ve antimikrobiyal ilaçlar gibi bazı farmasötik sınıflar söz konusu olduğunda bu oran \%60'lara kadar yükselmektedir [6,7].

Nörodejeneratif hastalıklar, dünya genelinde kanser ve kardiyovasküler hastalıklarından sonra önde gelen ölüm nedenleri arasındadır ve yeni tedavi stratejileri geliştirilmediği takdirde bu hastalık kaynaklı ölümlerin ilk sırada yer alacağı düşünülmektedir $[8,9]$. Bu hastalıklar, sinir sisteminin temel yapı taşı olarak bilinen nöron hücrelerinin yapı ve fonksiyon kaybına uğraması sonucu, sinirsel iletimin gerçekleşmemesi ile karakterize edilen kronik ve ilerleyici bir hastalık grubudur. Nörodejeneratif hastalıkların etiyopatogenezinde rol aldığ 1 düşünülen faktörlerden amiloid plaklar hücre diş1 $\beta$-amiloid proteinin birikimi iken nörofibriler yumaklar ise hücre içerisinde tau-proteininin anormal düzeylerde fosforilasyonu ve yanlış katlanması şeklinde meydana gelir. Bunların yanı sıra oksidatif stres, mitokondriyal disfonksiyon, iskemi, nöroinflamasyon, genetik mutasyonlar, endoplazmik retikulum hücresel stresi, kolinerjik disfonksiyon, aksonal taşıma zincir bozuklukları, nöronlarda anormal protein birikimi, viral, fungal ve prion kaynaklı nöronal apoptoz, bozulmuş mikrogliyal hücre aktivasyonu, eksitotoksisite ve nörotoksisite diğer etiyopatogenetik faktörler arasında yer almaktadır [8-13].

Nörodejeneratif hastalıkların en önemli ve en s1k karşılaşılan temsilcileri ise; Alzheimer (AH), Parkinson (PD), Huntington (HD), Amyotrofik Lateral Skleroz (ALS) ve Multiple Skleroz (MS) hastalıklarıdır. Nörodejeneratif hastalıklar her ne kadar farklı fizyolojik ve patolojik bulgulara sahip olsalar da hücresel mekanizmalarına bakıldığında benzer bulgular sergilemektedir $[10,11]$. Bu hastalıklarda, merkezi sinir sistemindeki makromoleküllerde artmış oksidatif hasar ile ilgili bulgular gözlemlenmiştir. Reaktif oksijen türleri (ROT), merkezi sinir sisteminde kortikal nöron ve sinir hücrelerinde kolinesteraz ve TYR enzimlerinin artışına sebep olup; kolinerjik iletimini engelleyerek, bunun sonucunda ise nöronlarda oksidatif stres ve apoptozu artırarak nörodejenerasyona neden olduğu bildirilmiştir $[12,13]$. Nörodejeneratif hastalıkların tedavisi için geliştirilen mevcut ilaçlar, kesin bir tedavi yöntemi sunmayıp, sadece hastalığın seyrini yavaşlatma eğilimindedir. $\mathrm{Bu}$ nedenle, bu ilaçların keşfinde kolinesteraz ve TYR enzimlerine karşı inhibitör özellik sergileyen, antioksidan ve anti-inflamatuvar potansiyele sahip etken maddelerin geliştirilmesine yönelik çalışmalar hız kazanmıştır [9, 14].

Withania somnifera (ashwagandha), Ginseng, curcumin, resveratrol, Baccopa monnieri (su çöreği), Ginkgo biloba, Centella asiatica ve Lycium barbarum (wolfberry) gibi şifalı bitkiler ve flavonoidler, selastrol, trehaloz, likopen, sesamol, resveratrol ve kurkumin gibi doğal bileşikler, nörolojik hastalıkları önlemek veya nörolojik semptomları hafifletmek için in vivo veya klinik araştırmalarda kullanıldığ 1 rapor edilmiștir $[15$, 16]. Sunulan bu derlemede, nörodejeneratif hastalıkların hücresel ve moleküler mekanizmalarını ve bu hastalıkların tedavisinde bütünleyici ve tamamlayıcı tıp alanında kullanılma potansiyeline sahip olan tıbb1 bitkiler ve bu bitkilerden elde edilen doğal bileşiklerin önemi vurgulanmıştır.

\section{NÖRODEJENERASYON}

Nörodejenerasyon, insan beynindeki nöronların doğrudan etkilendiği durumlarda meydana gelen ve nöral işlev kayıpları ile sonuçlanan olaylar dizinidir. Sinir hücrelerinin rejenerasyon yeteneklerinin olmaması bu olayın en önemli nedenlerinden birisidir [17, 18, 19]. Nörodejenarasyon birçok farklı nedenden dolayı meydana gelmekle birlikte; büyük bir kısmı canlılarda meydana gelen mutasyonlara bağlı olarak ortaya çıkmaktadır. Bu mutasyonlar, hastalıkla doğrudan ilişkili olabildiği gibi bazı durumlarda indirekt olarak görev yapan genlerden dolayı da meydana gelebilmektedir $[17$, 18, 20]. Nörodejenerasyon kaynaklı birçok hastalığın ortak özelliği mutasyona uğrayan genlerde sitozinadenin-guanin (CAG) nükleotit tripletlerinin tekrarlanmasıdır. Bu tekrarlamanın sonucunda, glutamin amino asidi meydana gelmekte ve hücrede fazladan oluşan glutamin ise; yanlış protein katlanmalarına, hücre içi lokalizasyon bozukluklarına ve diğer proteinler ile anormal interaksiyonlar ile meydana gelen toksik formdaki kaskadlara neden olmaktadır [21, 22]. Yapısal olarak normal olmayan proteinlerin hücre, doku ve organlarda fonksiyon bozukluğu oluşturması olayına 'proteopati' adı verilir [23]. Yanlıș konfigürasyondan dolayı proteinler bu süreçte toksik etki oluştururlar veya fonksiyonlarını kaybederler [24]. Alzheimer, Parkinson ve Prion hastalığı gibi nörodejeneratif hastalıklarının kaynağ1 olarak proteopati olayı sorumlu tutulmaktadır. Alzheimer hastalığının sebeplerinden olan beta amiloid ( $\beta$-amiloid) kalıntıları ile nörofibriler yumakların oluşumu bu durumun en iyi örnekleri olarak literatürlerde belirtilmiştir [17, 20, 25]. Diğer bir faktör ise, yanlış katlanmış veya işlenmemiş bu proteinlerin sağlıklı bir şekilde ortadan kaldırılamamasıdır. Bu aşamadaki temel sorun protein degredasyon süreçlerindeki eksikliklerden ileri gelmektedir. Degredasyon işlemleri yanlış gittiğinde hastalıkların oluşumundaki temel etken olarak kabul edilen ve hücre veya dokularda anormal olarak biriken protein kalıntıları meydana gelmektedir [26]. Bu nedenle mevcut araştırmalar bu yolaklardaki enzimlerin işlevsizliğinden 
ziyade; ilgili enzimlerin neden yanlış işlev gösterdiği üzerinde yoğunlaşmış durumdadır $[18,27]$.

Nörodejenerasyon sonucunda ortaya çıkma olasılığı en fazla olan patalojilerin başında; Alzheimer, Parkinson, Huntington ve Amyotrofik Lateral Skleroz hastalıkları gelmektedir. Bunun dışında daha az sıklıkla görülen; Prion, Spinoserebellar Ataksi, Spinal Müsküler Atrofi ve Motor nöron hastalıkları da nörodejeneratif hastalık türleri içerisinde yer almaktadır [13,17]. Bu hastalıkları birbirinden ayıran en önemli fark, hastalık sürecinde bozukluktan etkilenen hücre veya doku tiplerinin birbirinden farklı olmasıdır. Örneğin; Alzheimer hastalığında nöronların yaygın hasarı hipokampus ve nörokortekste çok ciddi düzeyde iken; bunun tam tersi olarak Parkinson hastalığında beyin ve korteks bölgesindeki nöronlar hasardan etkilenmezken, substantia nigradaki dopaminerjik nöronlarda yaygın hasar söz konusudur [25, 28, 29].

\section{NÖRODEJENERATIF BOZUKLUKLAR İLE İLISSKİLI ENZİMLER}

Enzimler, biyolojik sistemlerde yer alan protein veya proteid yapısındaki biyomoleküllerdir. Canlı organizmalarda gerçekleșen metabolik süreçlerde ve doku içerisinde meydana gelen biyokimyasal reaksiyonlarda katalizör olarak rol oynamaktadırlar [30, 31]. Enzimlerde protein yapıyı oluşturan amino asitlerin dizilişi, sayısı ve sırası belirli bir düzen içerisindedir; bu durum enzimin substrata özgüllüğünü ve her enzimin eşsiz üç boyutlu yapıya sahip olmasını sağlamaktadır
[31]. Enzimlerin büyük bir kısmı protein yapısında iken, diğer bir kısmı ise farklı maddeler ihtiva etmektedir [30]. Protein yapısında olan enzimlerde; proteinlerin primer, sekonder, tersiyer ve kuaterner yapısinı koruması, enzimin aktifliği açısından oldukça önemlidir. Enzimler denatarüsyona uğradıklarında ya da amino asit birimlerine kadar parçalanmaları durumunda aktivitelerini kaybetmektedir [32].

Enzim komisyonu (EC) 1961 y1lında enzimleri katalizledikleri reaksiyonların çeşidine ve reaksiyon mekanizmalarına göre temel olarak altı ana sınıfa ayırırken; bu altı kategori, Ağustos 2018'de yeni bir sınıf olan translokazların eklenmesi ile yedi ana sınıfa ayrılmıștır. Enzimlerin genel olarak sınıflandırılması Tablo 1'de verilmiştir [30, 31].

Kolinesteraz enzimleri, plazma ve vücut sıvılarında bulunan kolinerjik ve non-kolinerjik dokularda geniş bir dağılıma sahip olan enzimlerdir. $\mathrm{Bu}$ enzimler subsrat özgüllüğüne, aşırı subsrat varlığındaki davranışlarına ve inhibitörlerine karşı duyarlılıklarına göre iki sınıfa ayrılmıştır. AChE veya gerçek kolinesteraz (AChE: E.C.3.1.1.7, asetilkolin asetilhidrolaz) ve bütirilkolinesteraz (BChE: $\quad$ E.C.3.1.1.8 açilkolin açilhidrolaz) spesifik olmayan kolinesteraz veya psödokolinesteraz olarak bilinir. AChE beyin ve eritrositlerde, yüksek konsantrasyonlarda bulunurken, $\mathrm{BChE}$ ise; serum, pankreas, karaciğer ve santral sinir sisteminde bulunmaktadır [33]

Tablo 1. Enzimlerin sınıflandırılması

\begin{tabular}{|c|c|c|}
\hline Enzim grubu & Katalizlediği reaksiyon & Örnek \\
\hline Oksidoredüktazlar & $\begin{array}{l}\text { Hidrojen ve oksijen atomunu veya bir elektronu bir substrattan bir diğerine } \\
\text { taşırlar. }\end{array}$ & $\begin{array}{l}\text { Dehidrogenezlar } \\
\text { Oksidazlar }\end{array}$ \\
\hline Transferazlar & Spesifik bir grubu (fosfat, metil vs.) bir substrattan diğerine taşırlar. & $\begin{array}{l}\text { Transaminazlar } \\
\text { Kinazlar }\end{array}$ \\
\hline Hidrolazlar & Substratı hidroliz ederler. & Esterazlar \\
\hline İzomerazlar & Substratın molekül formunu değiştirirler. & $\begin{array}{l}\text { Fosfohekzoizomeraz } \\
\text { Fumaraz }\end{array}$ \\
\hline Liyazlar & Bir grubu eklerken veya çıkarırken hidroliz etmeden taşırlar. & $\begin{array}{l}\text { Dekarboksilazlar } \\
\text { Aldozlar }\end{array}$ \\
\hline Ligazlar (Sentetazlar) & Yeni bağlar aracılı̆̆g ile iki molekülün birleşmesini katalizler. & Sitrikasit sentetaz \\
\hline Translokazlar & $\begin{array}{c}\text { İyonların ve moleküllerin hücre boyunca translokasyonunu veya membranlar } \\
\text { içinde ayrılmalarını katalizler. }\end{array}$ & $\begin{array}{l}\text { ATP'nin ADP'ye } \\
\text { defosforilasyonu }\end{array}$ \\
\hline
\end{tabular}

*Sunulan veriler Tao ve ark., 2020; Vandenberghe ve ark, 2020'den alınmıștır.

$\mathrm{AChE}$ ve $\mathrm{BChE}$ nöronal sistemi etkileyen enzimler olup, aktivitelerinin azalması durumunda nörodejeneratif hastalıklar arasında en sık görülen Alzheimer hastalığının gelişimine ve ilerlemesine neden olmaktadır $[19,25,32,34]$. Alzheimer hastalığından sonra en sik görülen nörodejeneratif hastalık olan, Parkinson hastalığ 1 ise beyinde dopamin üreten bölgedeki hücre kayb1 nedeniyle, dopamin eksikliğinden kaynaklanan bir hastalıktır [35]. Oksiredüktazlar sınıfı bir enzim (EC 1.14.18.1) olan tirozinaz, insan beyninde nöromelanin oluşumunda rol oynamakta ve bu süreçte dopaminin oksidasyonu ile dopakinonları oluşturmaktadır.
Dopakinonun aşırı üretildiği durumlarda ise, sinir hasarı ve hücre ölümüne neden olmaktadır. $\mathrm{Bu}$ sebeple, tirozinaz enzimi dopamin nörotoksisitesine yol açarak Parkinson ve Hungtington hastalığı gibi nörodejeneratif hastalıklardan sorumlu olabileceği ileri sürülmektedir $[28,35,36]$

Son zamanlarda daha da önemli hale gelen ve immün hastalıklar, metabolik bozukluklar, kanser, kardiyovasküler ve nörodejeneratif hastalıklar gibi pek çok hastalığın tedavisinde kullanılan ilaçların, büyük bir kısmına enzim inhibitörleri dahil edilmiştir [37]. Enzim 
inhibitörleri (baskılayıcıları), enzimlerin in vivo ve in vitro aktivitelerini yavaşlatan veya sonlandıran küçük molekül ağırlığındaki maddeler olup, bu inhibitörlerin aktif olarak etkisini gösterdiği mekanizma ise 'enzim inhibisyonu' olarak adlandırılmaktadır [38]. Enzimlerin inhibisyona uğraması, biyolojik sistemlerin en önemli kontrol mekanizmalarıdır. Birçok kimyasal madde, ilaç ve zehirli bileşikler de etkilerini bu mekanizma aracılığı ile gerçekleştirmekte veya gerçekleştirememektedir. Enzim inhibitörleri bu özelliklerinden dolayı birçok fizyolojik durumda ilaç olarak da kullanılmaktadır. Ayrıca enzim inhibitörleri kullanılarak biyokimyasal reaksiyonların hızının düşürülmesi ya da tamamen durdurulması birçok hastalığın tedavisinde umut vaat eden bir gelişme olmuştur. $\mathrm{Bu}$ nedenlerle enzim inhibisyonu, enzim mekanizmalarının aydınlatılması çalışmalarında ve farmasötik alanda oldukça ilgi çeken bir araştırma konusu haline gelmiştir. Doğal ürünler enzimler ile reaksiyona girerek enzimlerin aktivitesini kontrol edebilmekte ve aynı zamanda sentetik ilaçların oluşturduğu birçok olumsuz etkilerinden dolayı daha çok tercih edilmektedir [32]. Nörobilim alanında yapılan araştırmalar sonucunda son zamanlarda literatürde nöroprotektif (nöron koruyucu) etkisi olduğu öne sürülen moleküller keşfedilmiș ve bunların farklı serebral hasarlarda koruyucu etkileri olduğu kanıtlanmıştır [39].

\subsection{Kolinesteraz Enzimleri}

Kolinesterazlar, plazma ve diğer vücut sıvilarında bulunan kolinerjik veya non-kolinerjik dokularda geniş<smiles>CC(=O)OCC[N+](C)(C)C</smiles>

\section{Asetilkolin}

Şekil 1. Asetilkolinesteraz enziminin hidroliz mekanizması [44]

$\mathrm{Bu}$ reaksiyon sonucunda üretilen $\mathrm{ACh}$; sinaps öncesindeki nöronlarda bulunan şeffaf veziküller içerisinde depolanırken, çok küçük bir kısmı ise sitozolde serbest halde bulunmaktadır. Veziküller, nörona sinir uyarısı geldiğinde içeriğini sinaptik aralığa boşaltmaktadır. Sinaptik aralığa salgılanan ACh moleküllerinin büyük bir kısmı postsinaptik membran üzerinde yer alan reseptörlere bağlanır, bağlanamayan ACh'ler ise AChE enzimi tarafindan hidroliz edilir. Postsinaptik reseptörlere bağlanan $\mathrm{ACh}$ molekülleri, sinir uyarısının diğer nörona iletilmesiyle reseptörden ayrılır ve AChE tarafından yıkılır, böylece açı̆ga çıkan ACh yeniden kullanılmak üzere presinaptik nörona gönderilir (Şekil 2) [44, 45]. bir dağılıma sahip olan enzim grubudur. Canlı organizmalar da bulunan kolinesterazlar substrat özgüllüklerine ve inhibitörlerine olan duyarlılıklarına göre asetilkolin esteraz (AChE) ve bütirilkolin esteraz (BChE) olmak üzere 2 alt gruba ayrılmıştır [40, 41].

\subsubsection{Asetilkolinesteraz (AChE) enzimi}

Asetilkolinesteraz (AChE) enzimi; nörotrasmitter asetilkolini (ACh) hidrolizleyerek dokularda serbest veya fosfolipidlerle bileşik halde bulunan karboksilesteraz ailesine ait bir enzimdir. Hidrolize edilen asetilkolin biyolojik öneme sahip bir ester olup; karaciğer, dalak, eritrositler, sinir uçları ve beyinde bulunmaktadır. AChE, sinir gazları (diizopropil florofosfat) ve pestisitler gibi organofosfor bileşikler tarafından inhibisyon için birincil hedef olarak tespit edilmiştir [40, 42, 43]. Asetilkolin (ACh) aracilı nörotransmisyon (sinir iletimi) sinir sisteminin fonksiyonunu yerine getirebilmesi için oldukça önemlidir. ACh; kolinasetiltransferaz (ChAT) tarafindan katalizlenen reaksiyon sonucu oluşan, asetil-ko-A'dan gelen asetil ve kolinin birleştirilmesi sonucu tanımlanan ilk nörotransmitterdir. AChE'nin katalitik aktivitesi oldukça yüksek olup; saniyede 25.000 ACh molekülünü hidroliz reaksiyonuyla (Şekil 1) asetat ve kolin birimlerine dönüştürebilmektedir [42, 43, 44].

\section{Asetat \\ Kolin}

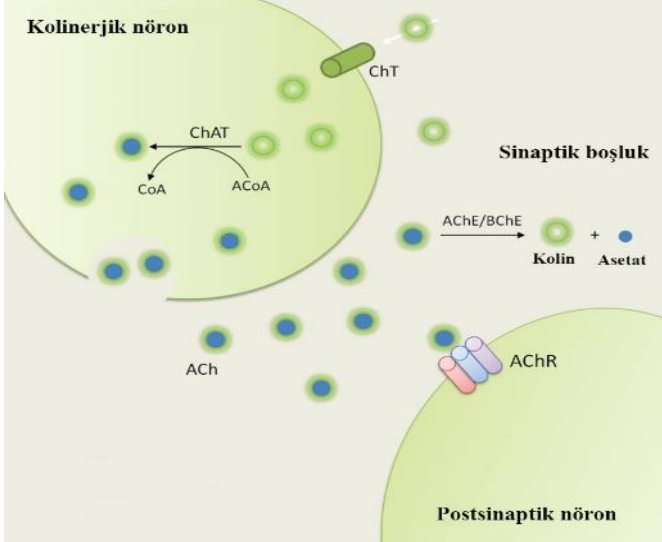

Sekil 2. Asetilkolinesteraz enziminin sinir hücrelerindeki fonksiyonu [45]

Nöron ve akson sinirsel iletişim kaybı ile başlayan bu gibi hastalıklar, sinir hücrelerinden daha düşük seviyelerde asetilkolin salınmasına neden olmaktadır $[25,46]$. Düşük konsantrasyondaki nörotransmitter düzeylerinde sinir iletilerinin devamlılığının sağlanması ve bilgilerin aktarımı daha da güçleşmektedir. Elbette ki; 
bu durumu düzeltmek ve sinirsel iletimin devamlılığını sağlamak için günümüzde birçok çalışma stratejileri yapılmakta; bu stratejiler (1) ACh benzeri moleküllerin verilmesi veya (2) ACh'ın yıkımına neden olan ve AChE enzimini inaktif hale getiren kolinesteraz inhibitörlerinin kullanılması şeklindedir $[40,47]$.

\subsubsection{Bütirilkolinesteraz (BChE) enzimi}

Bütirilkolinesteraz enzimi (BChE) yaklaşık olarak 342 $\mathrm{kDa}$ ağırlığında ve karaciğer tarafından sentezlenerek kana karışan tetramerik bir glikoproteindir. BChE; memelilerde biyolojik substratı olmayan bir enzim olup; BChE aktivitesinin kolesterol ve LDL (düşük yoğunluklu lipoprotein) kolesterol derişimi ile ilgili olduğu düşünülmektedir. $\mathrm{BChE}$; ince bağırsak, yağ dokusu, beyin ve akciğer gibi farklı dokularda bulunmaktadır ve bütirilkolini, bütirat ve koline hidrolize etmektedir (Şekil 3) [19, 34, 44].<smiles>CCCC(=O)OCC[N+](C)(C)C</smiles>

Bütirilkolin<smiles>[3H][OH+]C(=O)CCC</smiles>

Bütirat
Kolin

Şekil 3. Bütirilkolinesteraz enziminin hidroliz mekanizması [44]<smiles>N/C(=C\c1ccc(O)cc1)C(=O)O</smiles>

Tirozin<smiles>CC(Cc1ccc(O)c(O)c1)C(=O)O</smiles>

DOPA<smiles>Oc1cc2cc[nH]c2cc1O</smiles><smiles>CCCC</smiles>

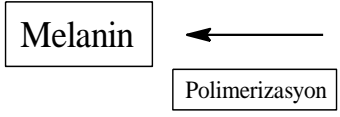<smiles>N/C(=C\C1=CC2OC2C(=O)O1)C(=O)O</smiles><smiles>O=C1C=C2CC(C(=O)O)C3=CC2OC1N3</smiles>

$\mathrm{H}$

Dopakrom

BChE'1n esteraz aktivitesi, organofosfat ve karbamat yapılı bileşiklerin asetilkolinesteraza ulaşamadan dolaşımdan temizlenmesinde ve asetilkolinesteraz yokluğunda kolinerjik sinir sisteminin kontrolünde rol oynar [34]. BChE'ın nöronsal dağılımına bakıldığında, serebral korteks alanların büyük bir kısmında, özellikle somatosensör sistem, singulat ve görme kortekslerinde, amigdala ve hipokampal (beyindeki beyaz çıkıntı) oluşumunda yer aldığı görülmektedir [25]. Bu enzim, sağlıklı beyinde nöron ve glial hücrelerde bulunurken; Alzheimer hastalarında amiloid $\beta$ - plaklar ve nörofibriller yumaklarda bulunmaktadır [19, 25]. Yüksek düzeylerde ki BChE konstrasyonları, Alzheimer hastalığının semptomları olan amiloid $\beta$ - plakların ve nörofibriler yumakların oluşumu ve gelişiminde önemli derecede rol oynamaktadır [25]. Yapılan çalışmalar sonucunda Alzheimer hastalarının beyinlerinde bütirilkolinesteraz miktarının normal seviyelere göre oldukça fazla olduğu saptanmıştır. $\mathrm{Bu}$ nedenle asetilkolinesteraz enzimini inhibe eden ilaçların aynı zamanda; bütirilkolinesteraz enzim inhibisyonunda da ilgili olabileceği düşünülmektedir [19, 25, 34].

\subsection{Tirozinaz (TYR) Enzimi}

Oksidoredüktaz sınıfı bir enzim (EC.1.14.18.1) olan tirozinaz, aynı zamanda polifenol oksidaz, fenolaz, katekol oksidaz, kresoz ve katekolaz olarak da bilinen bir enzimdir [48]. Tirozinaz (TYR), ilk kez 1856 yılında Schobenbein tarafindan mantar içerisinde keşfedilmiş, dinükleer bakır taşıyan bir enzimdir. Bu enzim birçok bitki dokusunda, bazı mantarlarda ve böceklerde de bulunmaktadır. Tirozinaz enzimi; cilt, saç ve göz rengi pigmentasyonu, sklerotizasyon olayı (böcekler kutikulanın sertleşmesi), birincil bağışıklık yanıtı ve konakçı savunması gibi birçok temel biyolojik olaydan sorumludur [28, 36, 48]. TYR, melanositler tarafindan 'melanogenezis' adı verilen kompleks bir süreç sonucunda üretilen melaninin biyosentezi sırasında hiz sınırlayıcı olarak ilk iki basamağı katalizleyen bir enzimdir [48]. Melaninin deride anormal şekilde birikmesi sonucunda hiperpigmentasyon ile ilişkili cilt rahatsızlıkları ortaya çıkmakta ve genellikle cilt üzerinde koyu renkli lekeler meydana getirmektedir. Deride meydana gelen hiperpigmentesyon tedavisi için klinikte 
hidrokinonlarla beyazlatma, retinoitler ile antiinflamatuvar tedavi ve tirozinaz inhibitörlerinin kullanımı söz konusudur. TYR inhibitörleri; kozmetik sektöründe 'cilt beyazlatıcı' (skin-whitening) etkisinden dolayı çok fazla kullanılmaktadır [28, 36, 49]. Ayrıca meyve ve sebzelerin işlenmesinin ardından enzimatik kararmaya neden olan TYR enzimi; ürünün kalitesini düşürerek maddi kayıplara neden olmaktadır. Bu amaçla gıda endüstrisinde hasat ve işleme sonrası enzimin aktivitesinin minimuma indirebilmek amaçlanmaktadır $[28,36,48]$.

Tirozinaz (TYR), melanin sentezinin kritik basamaklardan olan monofenollerin orto-difenollere hidroksilasyonunu ve orto-difenollerin de orto-kinonlara oksidasyonunu katalizleyen yapısında iki adet bakır atomu içeren bir enzimdir (Şekil 4) [28, 36, 48]. Bununla birlikte tirozinaz; tirozinin L-DOPA hidroksilasyonunu ve bunun ardindan ise L-DOPA oksidasyonunu katalizleyerek melanin biyosentezinde rol oynamaktadır [28, 36, 48, 49]. Ayrıca, tirozinaz enzimi insan beyninde nöromelanin oluşumunda rol alarak dopaminin oksidasyonu ile nöromelanin kaynaklı nörotoksisiteye sebep olmaktadır [35, 36, 39, 48]. Bu enzim, önemli nörodejeneratif rahatsızlıklardan biri olan Parkinson hastalığının patolojisinde ve fizyolojisinde; beyinde motor fonksiyonların gerçekleştirilmesinden sorumlu bölge olan bazal ganglionlardan substantia nigra bölgesindeki dopaminerjik nöronlarda hasar oluşturduğu gözlemlenmiştir [35, 36, 51]. Buradaki nöronlar birbirleriyle dopaminerjik ileti ile etkileşmektedir. $\mathrm{Bu}$ yolakta 5-S-sisteinil- dopamin katalizlediği oksidasyon reaksiyonu sonucu, bazı nörotoksik metabolitlerin oluşumuna yol açtığ 1 için Parkinson hastalarında dopamin toksisitesi gözlenmektedir [48]. Bu nedenle Parkinson hastalarında tirozinaz enzimi inhibitörlerinin kullanılması yapılan çalışmalar sonucunda hız kazanmıştır. TYR enziminin en iyi bilinen inhibitörlerinden olan kojik asit başta olmak üzere çeşitli sentetik inhibitörler geliştirilmiş; ancak bunların toksik etkilerinin bulunması nedeniyle, alternatif olarak doğal inhibitörlere yönelik çalıșmalar gün geçtikçe artmaktadır $[36,52]$.

\section{NÖRODEJENERATİF HASTALIKLARIN TEDAVISINDE KULLANILAN TIBBİ BITTKILLER VE FITOKİMYASALLAR}

Nörodejeneratif hastalıklar, dünya genelinde milyonlarca insanı etkileyen multifaktöriyel, ilerleyici ve ölümle sonuçlanan bir hastalık grubudur. Yapılan araştırmalar doğrultusunda bu hastalıkların fizyopatolojisi; bilişsel ve davranışsal bozukluklar, demans, hafıza kaybı, kolinerjik dejenerasyon, dopaminerjik nöron hasarı, $A \beta$ plakların oluşumu, oksidatif stres, artmış veya azalmış AChE, BChE ve TYR enzim aktiviteleri, genetik mutasyonlar, eksitotoksisite ve nöronal hücre ölümü ile karakterize edilmiştir [15, 53, 58]. Bu hastalıkların henüz kesin bir tedavisi bulunmamakla birlikte, ilerleme sürecini yavaşlatan ve hastanın yaşam kalitesini iyileştiren bazı ilaçlar mevcuttur. Günümüzde kullanılan bu ilaçların en büyük handikapı ise düzenli kullanımda ciddi yan etkilerinin bulunmasıdır. Ancak tıbbi bitkiler ve bu bitkilerden izole edilen fitokimyasallar hedef alınarak uzun vadede yan etki profili düşük olan yeni yaklaşımlara ihtiyaç duyulmaktadır $[16,53,54,58,60$, 72]. $\mathrm{Bu}$ nedenle nörodejeneratif hastalıkların tedavisinde sıklıkla kullanılan ve literatürde bildirilen bazı tıbbı bitkiler, bitkilerin kullanılan kısımları ve bu hastalıklarda fayda sağladığı düşünülen fitokimyasalları ve bu bileşiklerin etki mekanizması Tablo 2'de özetlenmektedir.

Tablo 2. Nörodejeneratif hastalıkların tedavisinde kullanılan tıbbi bitkiler ve fitokimyasallar

\begin{tabular}{|c|c|c|c|c|}
\hline Bilimsel adı & Kullanılan kısmı & Fitokimyasallar & Etki mekanizması & Kaynaklar \\
\hline Acorus calamus L. & Rizom & $\alpha$-ve $\beta$ - asaron & AChE inhibitör aktivite & {$[16,53,54]$} \\
\hline Allium sativum $\mathrm{L}$. & Soğan & S-Allil sistein & $\begin{array}{l}\text { Dopamin toksisitesi, lipid peroksidasyonu } \\
\text { ve süperoksit }\left(\mathrm{O}_{2}^{\circ-}\right) \text { radikal üretiminin } \\
\text { azaltılması, gelişmiş süperoksit dismutaz } \\
\text { (SOD) aktivitesi göstermektedir. }\end{array}$ & {$[16,54,55]$} \\
\hline $\begin{array}{c}\text { Angelica } \\
\text { archangelica } \mathrm{L} \text {. }\end{array}$ & Kök, meyve & $\begin{array}{l}\text { angelik asit, angelisin, } \\
\text { umbeliferon, furanokumarin, } \\
\text { ksantotoksin, imperatorin }\end{array}$ & AChE ve BChE inhibitör aktivite & {$[53,56,57]$} \\
\hline $\begin{array}{l}\text { Bacopa monnieri } \\
\text { (L.) Wettst. }\end{array}$ & $\begin{array}{c}\text { Toprak üstü, rizom, } \\
\text { yaprak }\end{array}$ & $\begin{array}{c}\text { bacoside-A, bacoside, } \\
\text { betulinik asit, D-mannitol, } \\
\text { stigmasterol, stigmastanol, } \beta \text { - } \\
\text { sitosterol }\end{array}$ & $\begin{array}{l}\text { Kolinerjik dejenerasyonu inhibe ederek, } \\
\text { hafiza artırıcı etki sergiler. }\end{array}$ & {$[15,16,54,58]$} \\
\hline $\begin{array}{l}\text { Bertholetia excelsa } \\
\text { Humb. \& Bonpl. }\end{array}$ & Meyve & lesitin & ACh konsantrasyonun artmasını sağlar. & {$[53]$} \\
\hline $\begin{array}{l}\text { Biota orientalis (L.) } \\
\text { Endl. }\end{array}$ & Yaprak & $\begin{array}{l}\text { 15-metoksipinusolidik asit, } \\
\text { izopimaran diterpen, ent- } \\
\text { izopimara-15-en-3-alfa, } \\
\text { lambertianik asit, 15-dien-18 } \\
\text { oik asit, 8-alfa-diol diterpenler, }\end{array}$ & $\begin{array}{l}\text { AD hastalığının tedavisinde fosfodiesterazı } \\
\text { inhibe ederek, nöroprotektif etki } \\
\text { göstermektedir. }\end{array}$ & [16] \\
\hline $\begin{array}{l}\text { Camelia sinesis (L.) } \\
\text { Kuntze }\end{array}$ & Yaprak & Epikateşin-3-gallat & $\begin{array}{l}\text { PD’da substantia nigra bölgesinde demir } \\
\text { birikimini azaltarak, beyinde demir } \\
\text { homeostazını sağlayarak dopaminerjik } \\
\text { nöronları ve dopamin düzeylerini } \\
\text { korumaktadır. Ayrıca A } \beta \text { plakların } \\
\text { oluşumuna neden olan enzimleri inhibe } \\
\text { ederek, plak oluşumunu engeller. }\end{array}$ & {$[16,59]$} \\
\hline
\end{tabular}


Tablo 2 (Devamı). Nörodejeneratif hastalıkların tedavisinde kullanılan tıbbi bitkiler ve fitokimyasallar

\begin{tabular}{|c|c|c|c|c|}
\hline Bilimsel adı & Kullanılan kısmı & Fitokimyasallar & Etki mekanizması & Kaynaklar \\
\hline Cannabis sativa $\mathrm{L}$. & Toprak üstü & $\begin{array}{c}\text { kannabidiol (CBD), } \\
\Delta 9 \text {-tetrahidrokanabinol } \\
\text { (THC) }\end{array}$ & $\begin{array}{l}\text { A } \beta \text { proteinlerinin üretimini yavaşlatarak, } \\
\text { sinirsel iletime yardımcı olur. }\end{array}$ & {$[60,61,62]$} \\
\hline Cassia obtusifolia Linn. & Tohum & $\begin{array}{l}\text { rubrofusarin, } \\
\text { izorubrofusarin }\end{array}$ & $\begin{array}{l}\text { AChE ve BChE inhibitör aktivite sergiler. } \\
\text { PD'da beyinin substantia nigra ve strium } \\
\text { bölgelerinde dopaminerjik nöron hasarına } \\
\text { karşı nöroprotektif etki gösterir. }\end{array}$ & {$[16,54,63]$} \\
\hline $\begin{array}{l}\text { Celastrus paniculatus } \\
\text { Willd. }\end{array}$ & Tohum & $\begin{array}{l}\text { trigliserit, serbest yağ } \\
\text { asitleri, digliserit, } \\
\text { esterleşmiş steroller, } \\
\text { monogliserit }\end{array}$ & $\begin{array}{l}\text { Kolinerjik aktiviteye sahip olup, hafizayı } \\
\text { güçlendirir ve dopamin nörotoksisitesini } \\
\text { engeller. }\end{array}$ & {$[16,54,58]$} \\
\hline Centella asiatica $\mathrm{L}$. & Yaprak & $\begin{array}{l}\text { asiatik asit, asiyatikozid, } \\
\text { madekassik asit }\end{array}$ & $\begin{array}{l}\text { Oksidatif stres ve } \beta \text {-amiloid seviyelerini } \\
\text { azaltarak, hafiza güçlendirici etki gösterir. }\end{array}$ & {$[15,16,53,54]$} \\
\hline $\begin{array}{l}\text { Chaenomeles speciosa } \\
\text { (Sweet) Nakai }\end{array}$ & Meyve & $\begin{array}{l}\text { Rutin, kateşin ve } \\
\text { epikateşin }\end{array}$ & $\begin{array}{c}\text { AChE ve BChE inhibitör aktivite, PD } \\
\text { hastalarında dopamin taşınımının kontrol } \\
\text { edilmesi, nörotoksisitenin engellenmesi ve } \\
\text { TYR enzim aktivitesinin korunmasını } \\
\text { sağlar. }\end{array}$ & {$[16,64]$} \\
\hline $\begin{array}{l}\text { Citrus sinensis (L.) } \\
\quad \text { Osbeck }\end{array}$ & Meyve & $\begin{array}{l}\text { flavon, flavon } \\
\text { glikozitleri, naringenin, } \\
\text { polymethoxyflavones }\end{array}$ & $\begin{array}{c}\text { PD'da substantia nigra bölgesinde } \\
\text { dopaminerjik nöronların toksisitesini ve } \\
\text { TYR enziminin hidroksilasyonunu } \\
\text { yavaşlatır. }\end{array}$ & {$[16]$} \\
\hline Coffea arabica $\mathrm{L}$. & Tohum & $\begin{array}{l}\text { kafein, kafeik asit, } \\
\text { klorojenik asit }\end{array}$ & $\begin{array}{l}\text { A } \beta \text { proteinlerinin üretimini baskılayarak ve } \\
\text { adenozin reseptör antagonist nöronları } \\
\text { eksitotoksisiteden koruyarak, oksidatif } \\
\text { stresi azaltabilmektedir. Ayrıca PD'da } \\
\text { striatal dopamin seviyelerinin ve dopamin } \\
\text { taşıyıcı bağlanma bölgelerinin kaybını } \\
\text { azaltıcı aktivite gösterir. }\end{array}$ & {$[16,54,65,66]$} \\
\hline Collinsonia canadensis L. & Kök & karvakrol,timol & $\begin{array}{l}\text { AChE enzimini inhibe ederek, ACh } \\
\text { yıkımını engeller. }\end{array}$ & {$[16,53,67]$} \\
\hline $\begin{array}{l}\text { Commiphora wightii } \\
\text { (Arn.) Bhandari }\end{array}$ & Reçine & $\begin{array}{l}\text { terpenler, seskiterpenler, } \\
\text { kumin aldehit, öjenol, } \\
\text { keton steroidleri Z- ve E- } \\
\text { guggulsteronları, I,II ve } \\
\text { III guggulsteronları }\end{array}$ & $\begin{array}{c}\mathrm{A} \beta \text { ve ChAT düzeylerinin azalmasına } \\
\text { yardımcı olur ve hafıza güçlendirici etki } \\
\text { sağlar. }\end{array}$ & {$[16,54,58]$} \\
\hline $\begin{array}{l}\text { Convolvulus pluricaulis } \\
\text { Chois. }\end{array}$ & Toprak üstü & $\begin{array}{l}\text { konvolin, konvolidin, } \\
\text { konvolvin, konvosin, } \\
\text { konvolamin, konfelin, } \\
\text { kampferol, fitosteroller }\end{array}$ & $\begin{array}{l}\text { Korteks ve hipokampusta } \mathrm{AChE} \text { enzim } \\
\text { inhibisyonu sağlayarak nöroprotektif etki } \\
\text { gösterir. }\end{array}$ & $\begin{array}{l}{[15,16,54,58,} \\
68]\end{array}$ \\
\hline Crocus sativus $L$. & Stigma & $\begin{array}{l}\text { gentisik asit, gallik asit, } \\
\text { likopen, krosin, } \alpha \text { - ve } \beta \text { - } \\
\text { karoten, zeaksantin, } \\
\text { pikrokrosin, safran }\end{array}$ & $\begin{array}{l}\text { AChE enzim aktivitesini azaltarak ACh } \\
\text { seviyelerinin artmasını sağlar. A } \beta \text { ve tau } \\
\text { proteinlerinin kümelenmesini engelleyerek } \\
\text { bilişsel bozuklukları azaltır. }\end{array}$ & {$[16,54,60,69]$} \\
\hline Curcuma longa $\mathrm{L}$. & Rizom & $\begin{array}{l}\text { kurkimin, demetoksi } \\
\text { kurkumin (DMC), } \\
\text { bidemetoksi kurkumin }\end{array}$ & $\begin{array}{c}\text { Endojen antioksidanları aktivite ederek } \\
\text { oksidatif stres durumunu, dopaminerjik } \\
\text { nöron dejenerasyonunu, A } \beta \text { oluşumunu } \\
\text { önler. Ayrıca AChE ve TYR enzim } \\
\text { hidroksilasyonunu engeller. }\end{array}$ & $\begin{array}{l}{[53,54,58,60} \\
\quad 70,71]\end{array}$ \\
\hline Galanthus nivalis L. & Soğan & $\begin{array}{l}\text { galantamin, izokinolin } \\
\text { alkaloitleri }\end{array}$ & $\begin{array}{c}\text { AChE enzimi spesifik inhibitörü olup, } \\
\text { nikotinik ACh reseptörlerini allosterik } \\
\text { olarak modüle ederek kolinerjik sinir } \\
\text { iletimini güçlendirir. }\end{array}$ & {$[16,53,54,60]$} \\
\hline Ginkgo biloba $\mathrm{L}$. & Yaprak & $\begin{array}{l}\text { terpen trilakton, } \\
\text { gingkolid A, B, C, J, } \\
\text { bilobalid, biflavonoid, } \\
\text { alkilfenoller, poliprenol, } \\
\text { proantosiyanidin }\end{array}$ & $\begin{array}{l}\text { Nöronların serbest radikaller, } \beta \text {-amiloid } \\
\text { kaynaklı nörotoksisite, lipid } \\
\text { peroksidasyonu ve oksidatif stres durumu } \\
\text { gibi faktörlerden korunmasını sağlar. Aynı } \\
\text { zamanda beyinde kan akışını hızlandırarak, } \\
\text { hafıza ve konsantrasyon gibi kognitif } \\
\text { fonksiyonlar üzerinde olumlu etki sağlar. }\end{array}$ & $\begin{array}{l}{[16,53,54,60,} \\
69]\end{array}$ \\
\hline Glycyrrhiza glabra L. & Kök & $\begin{array}{l}\text { glisirizin, glisirizik, } \\
\text { gliserinitik asit, } \\
\text { glukuronik asit }\end{array}$ & $\begin{array}{l}\text { AD ve PD'da apoptotik nöronal hücre } \\
\text { ölümüne karş1 nöroprotektif etki gösterir. }\end{array}$ & {$[16,53,54,72]$} \\
\hline $\begin{array}{c}\text { Huperzia serrata (Thunb.) } \\
\text { Trevis. }\end{array}$ & Tüm bitki & $\begin{array}{c}\text { lycoposerramine } \mathrm{H} \text {, } \\
\text { serratidine, obscurumine } \\
\text { A, } 11 \alpha-\mathrm{O}- \\
\text { asetillikopodin, } \\
\text { huperzine } \mathrm{A} \text {, huperzine } \\
\mathrm{B} \text {, huperzinine, likodin }\end{array}$ & Seçici ve güçlü AChE enzim inhibitörüdür. & {$[16,53,54,60]$} \\
\hline Hypericum perforatum $\mathrm{L}$. & Toprak üstü & $\begin{array}{l}\text { tanen, uçucu yağlar, } \\
\text { kolin, hiperisin, } \\
\text { hiperforin }\end{array}$ & $\begin{array}{l}\text { AD ve PD'da oksidatif stresi azaltarak } \\
\text { nörotoksisite ve nöroinflamasyonu önler. } \\
\text { A } \beta \text { peptidlerinin neden olduğu nöronal } \\
\text { hücre ölümüne karşı koruma sağlar. }\end{array}$ & {$[54,73]$} \\
\hline
\end{tabular}


Tablo 2 (Devamı). Nörodejeneratif hastalıkların tedavisinde kullanılan tıbbi bitkiler ve fitokimyasallar

\begin{tabular}{cccc}
\hline Bilimsel adı & Kullanılan kısmı & Fitokimyasallar & Etki mekanizması \\
\hline $\begin{array}{c}\text { Lavandula angustifolia } \\
\text { Mill. }\end{array}$ & Toprak üstü & $\begin{array}{c}\text { geraniol, linalil asetat, } \\
\text { ursolik asit, linalol, } \\
\text { borneol, luteolin, sineol, } \\
\text { bütirik asit, kamphor, } \\
\text { valerik asit }\end{array}$ & $\begin{array}{c}\text { AChE enzim inhibitör aktivitesini engeller. } \\
\text { Oksidatif stresi önleyerek bilişsel } \\
\text { bozuklukları iyileştirir ve nörolojik hasara } \\
\text { karşı korur. }\end{array}$ \\
\hline
\end{tabular}

asiklik ketonlar,

alkaloidler, amino AChE enzim inhibitörü olup, serbest

Lepidium meyenii Walp. Kök asitler, arginin, histidin, $\quad$ radikallere karşı antioksidan aktivite

fenilalanin, tirozin, $\quad$ sergileyerek, bilişsel bozuklukları antosiyanin, treonin, iyileştirir.

glucotropaeolin

\begin{tabular}{|c|c|c|c|c|}
\hline $\begin{array}{l}\text { Lycium barbarum L. I } \\
\text { (Wolfberry) }\end{array}$ & Meyve & $\begin{array}{l}\text { zeaksantin, lutein, } \mathrm{p}- \\
\text { kumarik asit, betain, } \\
\text { serebrozid, } \beta \text {-sitosterol }\end{array}$ & $\begin{array}{l}\text { A } \beta \text { proteini ile aktive olan kaspaz-3 ve } \\
\text { LDH aktivitesini zayıflatarak nöron } \\
\text { koruyucu etki gösterir. Ayrıca NF- } \kappa \text { B ve } \\
\text { MAP kinazı inhibe ederek oksidatif stres } \\
\text { durumunu ve glutamat kaynaklı } \\
\text { nörotoksisiteyi azaltır, nöronal hücre } \\
\text { ölümünü önleyici aktivite sergiler. }\end{array}$ & {$[15,75]$} \\
\hline $\begin{array}{l}\text { Magnolia officinalis } \\
\text { Rehder \& Wilson }\end{array}$ & Kabuk & magnolol ve honokiol & $\begin{array}{c}\text { AChE enzim inbisyonu ile bilişsel } \\
\text { bozuklukları engeller ve antioksidan } \\
\text { aktivite sergiler. }\end{array}$ & {$[16,53]$} \\
\hline Matricaria recutita $\mathrm{L}$. & Toprak üstü & $\begin{array}{l}\text { bisabolol oksit A, } \\
\text { bisabolol B, alfa- } \\
\text { bisabolol (levamenol), } \\
\text { cis-enyne-bicycloether, } \\
\text { bisabolon oksit A, } \\
\text { kamazulen,spathulenol, } \\
\text { E-beta-farnesen }\end{array}$ & $\begin{array}{c}\text { SOD, CAT ve GSH düzeylerini artırarak } \\
\text { beyinde yüksek düzeylerdeki lipid } \\
\text { peroksidasyonu ve oksidatif stres } \\
\text { durumunu azaltarak nöroprotektif etki } \\
\text { gösterir. }\end{array}$ & [76] \\
\hline Melissa officinalis L. & Toprak üstü & $\begin{array}{c}\text { kafeik, rozmanirik, } \\
\text { ferulik ve } \\
\text { hidroksisinamik asit, } \\
\text { izokuersitrin, luteolin-7- } \\
\text { O-glukozit, ramnositrin, } \\
\text { metil karnosoat } \\
\end{array}$ & $\begin{array}{l}\text { AChE enzim inhibitörü ve antioksidan } \\
\text { aktivitesi sayesinde AD hastalığının } \\
\text { önlenmesi ve tedavisinde fayda sağlar. }\end{array}$ & {$[16,5354,60]$} \\
\hline Morus alba $\mathrm{L}$. & $\begin{array}{l}\text { Kök kabuğu, } \\
\text { yaprak, meyve }\end{array}$ & $\begin{array}{l}\text { polifenoller, antosiyanin, } \\
\text { rutin, kuersetin, } \alpha \text { ve } \gamma \\
\text { tokoferol }\end{array}$ & $\begin{array}{l}\text { AChE ve BChE inhibitör aktivite, } \\
\text { mitokondriyal zar stabilizasyonu, } \\
\text { apoptozda yer alan Bcl-2, Bax ve kaspaz-3 } \\
\text { proteinlerinin ekspresyonunu düzenler. } \\
\text { Ayrıca substantia nigrada bradikinezi ve } \\
\text { dopaminerjik nöran hasarını hafifletir. }\end{array}$ & {$[16,77]$} \\
\hline Nigella sativa $\mathrm{L}$. & Tohum & timokinon & $\begin{array}{c}\text { PD'da MPP+ ve rotenon kaynaklı } \\
\text { dopaminerjik nöron hasarına karşı koruma } \\
\text { sağlar. Antioksidan, anti-inflamatuar, } \\
\text { AChE inhibisyonu, } \beta \text {-amiloid azalması, } \\
\text { artan serebral kan akış1, nörotransmiter } \\
\text { modülasyonu (ACh, 5-HT ve dopamin) } \\
\text { aktivitelerine sahiptir. }\end{array}$ & {$[16,78]$} \\
\hline Panax ginseng C.A.Mey. & Kök & $\begin{array}{l}\text { ginseng, ginsenosidler, } \\
\text { saponinler, 20(S)- } \\
\text { protopanaxadiol }(\mathrm{PPD}) \\
\text { 20(S)-protopanaxatriol } \\
\text { (PPT) }\end{array}$ & $\begin{array}{l}\text { Psikomotor ve bilişsel becerileri artırarak, } \\
\text { kolinerjik sistemi antioksidan, } \\
\text { nöroinflamatuar, nöroapoptotik, } \\
\text { nöroprotektif özellikleri sayesinde koruyup, } \\
\text { AD hasarını azaltıp, hasarlı nöronları } \\
\text { onarabilmektedir. }\end{array}$ & $\begin{array}{c}{[16,53,54,60,} \\
72]\end{array}$ \\
\hline $\begin{array}{l}\text { Piper methysticum } \\
\text { G. Forst. }\end{array}$ & Rizom & $\begin{array}{l}\text { 2, 5, 8-trimetil-1- naftol, } \\
\text { 8,11-oktadekadienoik } \\
\text { asit-metil ester, 5- } \\
\text { hidroksi-4',7- } \\
\text { dimetoksiflavanon } \\
\end{array}$ & $\begin{array}{l}\text { MAO-B inhibitörü olup, dopamin } \\
\text { seviyelerinin artmasını sağlar. }\end{array}$ & {$[16,79]$} \\
\hline Polygala tenuifolia Willd. & Kök & $\begin{array}{c}\text { ksanton, saponinler, } \\
\text { oligosakkarit esterleri }\end{array}$ & $\begin{array}{l}\text { AChE inhibisyonu ve ROS, kaspaz-3 } \\
\text { düzeylerinde azaltıcı etkiye sahiptir. }\end{array}$ & {$[16,60]$} \\
\hline $\begin{array}{l}\text { Polygonum multiflorum } \\
\text { Thunb. }\end{array}$ & Kök & $\begin{array}{l}\text { krizofanol, emodin, } \\
\text { physcion, noreugenin, } \\
\text { apigenin, aloeemodin, } \\
\text { rhein, daukosterol, beta- } \\
\text { sitosterol, stearik asit }\end{array}$ & $\begin{array}{c}\text { A } \beta \text { kaynaklı bilişsel eksiklikleri iyileştirir. } \\
\text { Oksidatif strese ve kortikal nöronlarda } \\
\text { glutamat kaynaklı nörotoksisiteye karşı } \\
\text { inhibitör etki gösterir. }\end{array}$ & {$[16,80]$} \\
\hline Pueraria thomsonii Benth. & Kök & $\begin{array}{l}\text { daidzein, daidzin, } \\
\text { genistein, puerarin }\end{array}$ & $\begin{array}{c}\text { 6-hidroksidopamin (6-OHDA) ile } \\
\text { indüklenen toksisiteye karşı nöroprotektif } \\
\text { etki gösterir ve kaspaz-3 ve kaspaz-8 } \\
\text { aktivasyonunu inhibe eder. }\end{array}$ & {$[16,81]$} \\
\hline Rheum glabricaule Sam. & Kök & $\begin{array}{c}\text { palmitik asit, } \\
\text { daukosterol, krizofanol- } \\
\text { 8-me eter, sitreorosein, } \\
\text { krizofanol-8-O-beta-D- } \\
\text { glukopiranozit } \\
\end{array}$ & $\begin{array}{c}\text { A } \beta \text { kaynaklı nörotoksisiteye karşı koruyucu } \\
\text { etki gösterir. }\end{array}$ & {$[16,54]$} \\
\hline
\end{tabular}


Tablo 2 (Devamı). Nörodejeneratif hastalıkların tedavisinde kullanılan tıbbi bitkiler ve fitokimyasallar

\begin{tabular}{|c|c|c|c|c|}
\hline Bilimsel adı & Kullanılan kısmı & Fitokimyasallar & Etki mekanizması & Kaynaklar \\
\hline Rosmarinus officinalis L. & Toprak üstü, yaprak & $\begin{array}{l}\text { apigenin, oleanolik asit, } \\
\text { rozmanirik, karsonik, } \\
\text { kafeik, betulinik ve } \\
\text { ursolik asit, karvakrol, } \\
\text { öjenol, timol, kamphor, } \\
\text { rosmaridifenol, rosmanol }\end{array}$ & $\begin{array}{l}\text { A } \beta \text { agregasyonu, AChE ve BChE } \\
\text { inhibitörü, nöroinflamasyon, } \beta \text {-sekretaz } \\
\text { (BACE-1) aktivitesi, lipid peroksidasyonu, } \\
\text { ROS seviyesini ve apoptotik sinyalleri } \\
\text { azaltarak dopaminerjik (DA) nöronal hücre } \\
\text { hasarına karşı koruyucu aktivite sergiler. }\end{array}$ & $\begin{array}{l}{[16,54,72,82,} \\
83]\end{array}$ \\
\hline Salix alba $\mathrm{L}$. & Yaprak, Kabuk & $\begin{array}{l}\text { salisin, salikortin, } \\
\text { populin, fragilin, } \\
\text { tremulasin, salisil alkol, } \\
\text { saligenin, sirinjin, } \\
\text { salisilik, kafeik ve } \\
\text { ferulik asit, vanilin, } \\
\text { salidrosid }\end{array}$ & $\begin{array}{l}\text { COX-1 ve COX-2'nin inhibitörü olup } \\
\text { nöroinflamatuar olarak hareket eder. }\end{array}$ & {$[16,54]$} \\
\hline Salvia officinalis $\mathrm{L}$. & Toprak üstü & $\begin{array}{l}\text { rozmarinik, oleik, } \\
\text { karsonik, tannik, ursolik, } \\
\text { fumarik, klorojenik, ve } \\
\text { kafeik asit, nikotinamid, } \\
\text { okaliptol, borneol, } \\
\text { thujone, cornsole } \\
\end{array}$ & $\begin{array}{l}\text { AChE ve BChE inhibe edici bileşiklerin } \\
\text { yanı sıra güçlü antioksidan özelliklere } \\
\text { sahiptir. }\end{array}$ & {$[16,60,72]$} \\
\hline $\begin{array}{l}\text { Scutellaria baicalensis } \\
\text { Fisch. }\end{array}$ & Toprak üstü & baicalin, baicalein & $\begin{array}{l}\text { Substantia nigra'da demir kaynaklı lipid } \\
\text { peroksidasyonunu ve alfa-sinüklein } \\
\text { agregatlarının dopaminerjik nöronlarda } \\
\text { birikimini azaltır. }\end{array}$ & {$[16]$} \\
\hline Sesamum indicum $\mathrm{L}$. & Tohum & $\begin{array}{l}\text { sesamin, sesaminol, } \\
\text { sesamol }\end{array}$ & $\begin{array}{l}\text { Hipokampus'da nöronları } \\
\text { nöroinflamasyona karşı koruma, sinapsların } \\
\text { aktivitelerini iyileştirerek, dopaminerjik } \\
\text { nörotoksisiteyi azaltır. Ayrıca tirozin } \\
\text { hidroksilaz, SOD ve katalaz ekspresyonunu } \\
\text { düzenler ve mikroglia hücrelerinde sitokin } \\
\text { IL-6' nın mRNA seviyelerini düşürerek } \\
\text { proinflamatuar aktivite gösterir. }\end{array}$ & {$[15,16]$} \\
\hline Terminalia chebula Rez. & Meyve & $\begin{array}{l}\text { Arjunglukozit-I, } \\
\text { Arjungenin, } \\
\text { chebulosides I ve II, } \\
\text { Şebulinik asit, Gallik } \\
\text { asit, punicalagin, Etil } \\
\text { gallat }\end{array}$ & AChE ve BChE inhibitör aktivite sergiler. & {$[16,84]$} \\
\hline $\begin{array}{l}\text { Tripterygium wilfordii } \\
\text { Hook. f. }\end{array}$ & Kök, gövde & selastrol & $\begin{array}{l}\text { PD ve AD’da Bcl-2 ekspresyonunu } \\
\text { artırarak, nöronal apoptozu inhibe eder ve } \\
\text { nöroinflamatuar aktivite sergiler. }\end{array}$ & {$[85,86]$} \\
\hline $\begin{array}{l}\text { Uncaria rhynchophylla } \\
\text { (Miq.) Jacks }\end{array}$ & Gövde, kanca & $\begin{array}{l}\text { rinkofilin, corynoxeine, } \\
\text { korinantin, hirsutin, } \\
\text { kateşin, epikateşin }\end{array}$ & $\begin{array}{l}\text { ROS türlerinde ve kaspaz-3 düzeyinde } \\
\text { azaltıcı, A } \beta \text { kaynaklı nörotoksisite, } \\
\text { nöroinflamasyon ve nörodejeneratif etki } \\
\text { sağlar. }\end{array}$ & {$[16,87]$} \\
\hline Urtica dioica $\mathrm{L}$. & Toprak üstü, yaprak & $\begin{array}{l}\text { asetilkolin, protein, } \\
\text { histamin, serotonin }\end{array}$ & Kolinerjik sistemi iyileştirir. & {$[16,54]$} \\
\hline Vitis vinifera $\mathrm{L}$. & Meyve & $\begin{array}{l}\text { kateşin, epikateşin, } \\
\text { antosiyanin, resveratrol }\end{array}$ & $\begin{array}{l}\text { A } \beta \text { ve tau proteinlerinin ekspresyonunu } \\
\text { inhibe ederek, antioksidatif, } \\
\text { nöroinflamatuar, antikolinesteraz ve } \\
\text { antiamiloidojenik aktiviteye sahiptir. }\end{array}$ & {$[16,60,88,89]$} \\
\hline $\begin{array}{l}\text { Withania somnifera }(\mathrm{L} .) \\
\text { Dunal }\end{array}$ & Kök, meyve & $\begin{array}{l}\text { Withanolides A-Y, } \\
\text { withasomniferin A, } \\
\text { dehidrowithanolide R, } \\
\text { withasomniferols A-C, } \\
\text { withaferin A, withanone }\end{array}$ & $\begin{array}{l}\text { Nöronal aksonların ve dentritlerin } \\
\text { rejenerasyonu, antioksidan aktivite ile } \\
\text { serbest radikallere karşı koruma, } \\
\text { nörodejeneratif hastalıklarda antiapoptotik, } \\
\text { antiinflamatuar ve nöroprotektif etki } \\
\text { gösterir. Ayrıca beyinin korteks, } \\
\text { hipokampus ve striatum kısımlarında GSH, } \\
\text { GST ve azalan ACh seviyelerini önemli } \\
\text { ölçüde artırır. }\end{array}$ & {$[16,53,54,90]$} \\
\hline Zingiber officinale Roscoe & Rizom & $\begin{array}{l}\text { zingeron, gingerols, 6- } \\
\text { şogaol, beta- } \\
\text { seskifellandren, } \\
\text { bisabolen, farnesen, } \\
\text { okaliptol, sitral, } \\
\beta \text {-phelladrene }\end{array}$ & $\begin{array}{l}\text { 6-OHDA kaynaklı dopamin kaybını ve } \\
\text { apoptotik nöral hücre ölümünü engeller. } \\
\text { ROS üretimi, A } \beta \text { oluşumu, } \mathrm{AChE} \mathrm{ve} \mathrm{BChE} \\
\text { enzimleri üzerinde inhibitör etki gösterir. }\end{array}$ & {$[16,72,91,92]$} \\
\hline
\end{tabular}

\section{SONUÇ VE ÖNERILLER}

Nörodejeneratif hastalıklar, nöronların yapı ve işlevinin ilerleyici kaybı (ve hatta ölümü) ile karakterize olan, bireyi ve toplumu büyük ölçüde etkileyen hastalıklardır. Günümüzde çoğu nörodejeneratif hastalığın gerçek nedeni tam olarak aydınlatılamamış olmakla birlikte; protein yıkımı, oksidatif stres, enflamasyon, çevresel faktörler, mitokondriyal bozukluklar, aile öyküsü ve nöronda anormal protein birikimi yaygın olarak incelenen nedenlerdir. Ayrıca, yaşlı insanlarda nörodejeneratif bozuklukların ve hastalıkların görülme sıklığının arttığı epidemiyolojik çalışmalar ile ortaya konulmuştur. $\mathrm{Bu}$ hastalıkların bireyler üzerinde geri 
dönüşümsüz bilişsel işlev bozukluklarına neden olduğu bilinmektedir. $\mathrm{Bu}$ nedenle, nörodejeneratif hastalıkların mümkün olan en erken evrede teşhis edilerek, prognozunun yavaşlatılması etkili tedavi stratejisi açısından son derece önemlidir. AD, PD, Huntington ve diğer nörodejeneratif bozukluklar, hücresel ve hücre altı seviyelerde ortak özellikleri paylaşmanın yanı sıra apoptoz, nekroptoz ve iltihaplanmaya yol açabilen çoğunlukla ortak moleküler sinyal yollarını kullanmaktadırlar. Günümüzde hastaların bilişsel fonksiyon kayıplarını yavaşlatmayı ve yaşam kalitesini artırmayı hedefleyen, Amerika Gıda ve İlaç Dairesi (Food and Drug Administration; FDA) tarafindan onaylı $\mathrm{N}$-metil-D-aspartat reseptör antagonisti olan memantin, kolinesteraz inhibitörü olarak rivastigmin, galantamin ve donepezil ilaçları nörodejeneratif hastalıkların mevcut tedavisinde kullanılmaktadır. Ancak bu ilaçların yarılanma ömürleri oldukça kısa olup, istenmeyen kimi yan etkileri nedeniyle klinik kullanımda kısıtlamaları olduğu bilinmektedir. Bu nedenlerden dolayı bitkisel kaynaklı nöroprotektif ilaçlar, güçlü terapötik potansiyelleri sayesinde umut verici yaklaşım olarak büyük ilgi görmektedir. Bununla birlikte; bitkisel ilaçların/doğal bileşiklerin potansiyeli, zayıf farmakokinetik özellikleri nedeniyle büyük ölçüde engellenmektedir. Bu sınırlamaların üstesinden gelmek için, son y1llarda bitkisel ilaçlar, nanoenkapsülasyon sistemleri ile çeşitli ilaç dağıtım formülasyonlarına dahil edilmektedir. Bu tür nanoformülasyonlar, ilacı gerekli dozlarda spesifik hücrelere hedefleyerek toksisitenin azaltılması sağlanacaktır. $\mathrm{Bu}$ alanda yapılacak çalışmalar ile, mevcut şifalı bitkilerin yanı sıra, nöroprotektif etkiye sahip bitkiler belirlenerek, ihtiva ettikleri etken maddelerin karakterizasyonları yapılmalı ve etki mekanizmaları preklinik ve klinik araştırmalar ile ortaya konulmalıdır.

\section{KAYNAKLAR}

[1] Gezici S, Sekeroglu N. Current perspectives in the application of medicinal plants against cancer: novel therapeutic agents. Anti-Cancer Agents Med Chem. 2019a; 19(1), 101-11.

[2] Baydar H. Tibbi ve aromatik bitkiler bilimi ve teknolojisi. (8.bask1). Ankara: Nobel Akademik Yayınlar1. 2020.

[3] Senkal BC. The role of secondary metabolites obtained from medicinal and aromatic plants in our lives. ISPEC J Agric Sci. 2020; 4(4), 1071-9.

[4] Sam S. Importance and effectiveness of herbal medicines. J Pharmacog Phytochem. 2019; 8(2), 354-7.

[5] Bozyel ME, Bozyel EM, Canlı K, Altuner EM. Anticancer uses of medicinal plants in Turkish traditional medicine. KSU J Agric Nat. 2019; 22, 465-84.

[6] Tesfahuneygn G, Gebreegziabher G. Medicinal plants used in traditional medicine by ethiopians: A review article. J Respir Med Lung Dis. 2019; 4(1), 1-3.

[7] [7] Ramakrishna W, Kumari A, Rahman N, Mandave P. Anticancer activities of plant secondary metabolites: Rice callus suspension culture as a new paradigm. Rice Sci. 2021; 28(1), 13-30.

[8] Gezici S, Sekeroglu N. Neuroprotective potential and phytochemical composition of acorn fruits. Ind Crop Prod. 2019b; 128, 13-7.

[9] Ahmad A, Patel V, Xiao J, Khan MM. The role of neurovascular system in neurodegenerative diseases. Molecular Neurobiol. 2020; 57(11), 4373 93.

[10] Scheiblich H, Trombly M, Ramirez A, Heneka MT. Neuroimmune connections in aging and neurodegenerative diseases. Trends Immunol. 2020; 41(4), 300-12.

[11] Teixeira MI, Lopes CM, Amaral MH, Costa PC. Current insights on lipid nanocarrier-assisted drug delivery in the treatment of neurodegenerative diseases. Eur J Pharm Biopharm. 2020; 149, 192217.

[12] Cassano T, Villani R, Pace L, Carbone A, Bukke VN, Orkisz S, Serviddio G. From Cannabis sativa to cannabidiol: Promising therapeutic candidate for the treatment of neurodegenerative diseases. Front Pharmacol. 2020; 11 (124), 1-10.

[13] Luthra R, Roy A. Role of medicinal plants against neurodegenerative diseases. Current Pharmaceutical Biotechnology. McKinnon, P. J. Maintaining genome stability in the nervous system. Nat Neurosci. 2021; 16(11), 1523.

[14] Senol FS, Sekeroglu N, Gezici S, Kilic E, Orhan IE. Neuroprotective potential of the fruit (acorn) from Quercus coccifera L. Turk J Agric For. 2018; 42(2), 82-7.

[15] Ratheesh G, Tian L, Venugopal JR., Ezhilarasu H, Sadiq A, Fan TP, Ramakrishna S. Role of medicinal plants in neurodegenerative diseases. Biomanuf Rev. 2017; 2(1), 1-16

[16] Lalotra S, Vaghela JS. Scientific reports of medicinal plants used for the prevention and treatment of neurodegenerative diseases. J Pharm Biosci. 2019; 15-25.

[17] Rekatsina M, Paladini A, Piroli A, Zis P, Pergolizzi JV, Varrassi G. Pathophysiology and therapeutic perspectives of oxidative stress and neurodegenerative diseases: a narrative review. Adv Ther. 2020; 37(1), 113-39.

[18] Guerreiro S, Privat AL, Bressac L, Toulorge D. CD38 in Neurodegeneration and Neuroinflammation. Cells. 2020; 9(2), 471.

[19] Ha ZY, Mathew S, Yeong KY. Butyrylcholinesterase: a multifaceted pharmacological target and tool. Curr Protein Peptide Sci. 2020; 21(1), 99-109.

[20] Wyss-Coray T. Ageing, neurodegeneration and brain rejuvenation. Nature. 2016; 539(7628), 180-6.

[21] Jeppesen DK, Bohr VA, Stevnsner T. DNA repair deficiency in neurodegeneration. Prog Neurobiol. 2011; 94(2), 166-200.

[22] McKinnon PJ. Maintaining genome stability in the nervous system. Nat Neurosci. 2013; 16(11), 1523.

[23] Walker LC, LeVine H. The cerebral proteopathies. Mol Neurobiol. 2000; 21(1), 83-95.

[24] Luheshi LM, Crowther DC, Dobson CM. Protein misfolding and disease: from the test tube to the 
organism. Curr Opin Chem Biol. 2008; 12(1), 2531.

[25] Jasiecki J, Wasąg B. Butyrylcholinesterase protein ends in the pathogenesis of Alzheimer's disease could BCHE genotyping be helpful in Alzheimer's therapy. Biomolecules. 2019; 9(10), 592.

[26] Dobson CM. Protein folding and misfolding. Nature. 2003; 426(6968), 884-90.

[27] Rubinsztein DC. The roles of intracellular proteindegradation pathways in neurodegeneration. Nature. 2006; 443(7113), 780-6.

[28] Kim YJ, Uyama H. Tyrosinase inhibitors from natural and synthetic sources: structure, inhibition mechanism and perspective for the future. Cell Mol Life Sci. 2005; 62(15), 1707-23.

[29] Scheff SW, Price DA. Alzheimer's disease-related alterations in synaptic density: neocortex and hippocampus. Journal of Alzheimer's Disease. 2006; 9(s3), 101-115.

[30] Tao Z, Dong B, Teng Z, Zhao Y. The classification of enzymes by deep learning. IEEE Access. 2020; $8,89802-11$.

[31] Vandenberghe L, Karp SG, Binder Pagnoncelli MG, von Linsingen Tavares M, Libardi Junior N, Valladares Diestra K, Viesser JA, Soccol CR. Classification of enzymes and catalytic properties. Biomass, Biofuels, Biochemicals: Advances in Enzyme Catalysis and Technologies. Elsevier. 2020; p.11-30.

[32] Bora N. Aristolochia bodamae Dingler (Aristolochiaceae) Kök Ekstraktlarının in vitro Antioksidan, Antibakteriyel ve Enzim İnhibisyon Aktivitelerinin Araștırılması. Yüksek Lisans Tezi, Ondokuz Mayıs Üniversitesi, Fen Bilimleri Enstitüsü; 2019.

[33] Pohanka M. Acetylcholinesterase inhibitors: a patent review (2008-present). Expert Opin Ther Pat. 2012; 22(8), 871-86.

[34] Xing S, Li Q, Xiong B, Chen Y, Feng F, Liu W, Sun H. Structure and therapeutic uses of butyrylcholinesterase: Application in detoxification, Alzheimer's disease, and fat metabolism. Med Res Rev. 2020; 41(2), 858-901.

[35] Nagatsu T, Nakashima A, Ichinose H, Kobayashi K. Human tyrosine hydroxylase in Parkinson's disease and in related disorders. J Neural Transm.

[36] Celikler O. Bitkisel Kaynaklı Yeni Tirozinaz İnhibitörlerinin Belirlenmesi Üzerinde Farmakognozik Araştırmalar. Doktora Tezi, Gazi Üniversitesi, Sağlık Bilimleri Enstitüsü; 2017.

[37] Copeland RA, Harpel MR, Tummino PJ. Targeting enzyme inhibitors in drug discovery. Expert Opin Ther Targ. 2007; 11(7), 967-78.

[38] Smith JH, Simons C. Development of enzyme inhibitors as drugs. Enzymes and their inhibitors drug development. CRC Press. 2004; 190-328.

[39] Lermi M. Isatis cappadocica'nın Antioksidan, Antimikrobiyal, Tirozinaz İnhibitör ve Sitotoksik Etkilerinin İncelenmesi. Yüksek Lisans Tezi, Karadeniz Teknik Üniversitesi, Sağlık Bilimleri Enstitüsü; 2018.

[40] Zilbeyaz K, Stellenboom N, Guney M, Oztekin A, Senturk M. Effects of aryl methanesulfonate derivatives on acetylcholinesterase and butyrylcholinesterase. J Bio Mol Toxic. 2018; 32(11), e22210.

[41] Turkan F, Atalar MN. The toxicological impact of some agents on glutathione S-transferase and cholinesterase enzymes. Toxicol. 2021; p. 281-90.

[42] Zhang P, Fu C, Xiao Y, Zhang Q, Ding C. Copper (II) complex as a turn on fluorescent sensing platform for acetylcholinesterase activity with high sensitivity. Talanta. 2020; 208, 120406.

[43] Chrouda A, Zinoubi K, Soltane R, Alzahrani N, Osman G, Al-Ghamdi YO, Jaffrezic Renault N. An acetylcholinesterase inhibition-based biosensor for aflatoxin B1 detection using sodium alginate as an immobilization matrix. Toxins. 2020; 12(3), 173.

[44] Koc F. Rutinhidrat'in Antioksidan Kapasitesinin Belirlenmesi ve İnsan Karbonik Anhidraz, Asetilkolinesteraz, Bütirilkolinesteraz Enzimleri Üzerine Etkisinin İncelenmesi. Yüksek Lisans Tezi, Atatürk Üniversitesi, Fen Bilimleri Enstitüsü; 2019.

[45] Dias C, Rauter AP. Carbohydrates and Glycomimetics in Alzheimer's Disease therapeutics and Diagnosis. In Carbohydrates in Drug Design and Discovery. Royal Sciety of Chemistry. 2015; p. 180-208.

[46] Tekin Z. Türkiye için Endemik Bir Tür Olan Nepeta congesta var. congesta'nın (Lamiaceae) Antioksidan Özelliklerinin ve Enzim İnhibitör Etkisinin Değerlendirilmesi. Yüksek Lisans Tezi, Necmettin Erbakan Üniversitesi, Fen Bilimleri Enstitüsü; 2018.

[47] Joubert J, Kapp E. Discovery of 9phenylacridinediones as highly selective butyrylcholinesterase inhibitors through structurebased virtual screening. Bioorganic Med Chem Lett. 2020; 30(9), 127075.

[48] Mendes E, Perry MDJ, Francisco AP. Design and discovery of mushroom tyrosinase inhibitors and their therapeutic applications. Expert Opin Drug Discov. 2014; 9(5), 533-554.

[49] Gillbro JM, Olsson MJ. The melanogenesis and mechanisms of skin-lightening agents-existing and new approaches. Int J CoS Sci. 2011; 33(3), 210221.

[50] Agarwal P, Singh M, Singh J, Singh RP. Microbial Tyrosinases: A Novel Enzyme, Structural Features, and Applications. In Applied Microbiology and Bioengineering. Academic Press. 2019; p. 3-19.

[51] Gasser T. Genetics of Parkinson's disease. J Neurol. 2001; 248(10), 833-40.

[52] Tocco G, Fais A, Meli G, Begala M, Podda G, Fadda MB, Berretta S. PEG-immobilization of cardol and soluble polymer-supported synthesis of some cardol-coumarin derivatives: Preliminary evaluation of their inhibitory activity on mushroom tyrosinase. Bioorganic Med Chem Lett. 2009; 19(1), 36-39.

[53] Singhal AK, Naithani V, Bangar OP. Medicinal plants with a potential to treat Alzheimer and associated symptoms. Int J Nutr Pharmacol Neurol Dis. 2012; 2(2), 84.

[54] Munawar T, Bibi Y, Ahmad F. Ethnomedicinal Study of Plants used for Neurodegenerative 
Diseases: A Review: Ethnomedicinal study of plants used for Neurodegenerative Diseases. Proceedings of the Pakistan Academy of Sciences: B. Life Envir Sci. 2020; 57(3), 13-26.

[55] Rojas P, Serrano-García N, Medina-Campos ON, Pedraza-Chaverri J, Maldonado PD, Ruiz-Sánchez E. S-Allylcysteine, a garlic compound, protects against oxidative stress in 1-methyl-4phenylpyridinium-induced Parkinsonism in mice. $\mathbf{J}$ Nutr Biochem. 2011; 22(10), 937-44.

[56] Sigurdsson S, Gudbjarnason S. Inhibition of acetylcholinesterase by extracts and constituents from Angelica archangelica and Geranium sylvaticum. Zeitschrift für Naturforschung C. 2007; 62(9-10), 689-93.

[57] Wszelaki N, Paradowska K, Jamróz MK, Granica S, Kiss AK. Bioactivity-guided fractionation for the butyrylcholinesterase inhibitory activity of furanocoumarins from Angelica archangelica L. roots and fruits. J Agric Food Chem. 2011; 59(17), 9186-93.

[58] Gupta A, Singh R, Kakar S. Alzheimer's Disease Treatment with Herbal Prospective. Int J Health Biologic Sci. 2019; 2(4), 13-8.

[59] Malar DS, Prasanth MI, Brimson JM, Sharika R, Sivamaruthi BS, Chaiyasut C, Tencomnao T. Neuroprotective properties of green tea (Camellia sinensis) in Parkinson's disease: A review. Molecules. 2020; 25(17), 3926

[60] Perry E, Howes MJR. Medicinal plants and dementia therapy: herbal hopes for brain aging. CNS Neurosci Ther. 2011;17(6), 683-98.

[61] Currais A, Quehenberger O, Armando AM, Daugherty D, Maher P, Schubert D. Amyloid proteotoxicity initiates an inflammatory response blocked by cannabinoids. NPJ Aging Mech Dis. 2016; 2(1), 1-8

[62] Cassano T, Villani R, Pace L, Carbone A, Bukke VN, Orkisz S, Serviddio G. From Cannabis sativa to cannabidiol: Promising therapeutic candidate for the treatment of neurodegenerative diseases. Front Pharmacol. 2020; 11, 124.

[63] Jung HA, Ali MY, Jung HJ, Jeong HO, Chung HY, Choi JS. Inhibitory activities of major anthraquinones and other constituents from Cassia obtusifolia against $\beta$-secretase and cholinesterases. J Ehnopharmacol. 2016; 191, 152-60.

[64] Turkiewicz IP, Wojdyło A, Tkacz K, Nowicka P, Golis T, Bąbelewski P. ABTS On-line antioxidant, $\alpha$-amylase, $\alpha$-glucosidase, pancreatic lipase, acetyland butyrylcholinesterase inhibition activity of Chaenomeles fruits determined by polyphenols and other chemical compounds. Antioxidants. 2020; $9(1), 60$.

[65] Chen JF, Steyn S, Staal R, Petzer JP, Xu K, Van der Schyf CJ, Schwarzschild MA. 8-(3Chlorostyryl) caffeine may attenuate MPTP neurotoxicity through dual actions of monoamine oxidase inhibition and A2A receptor antagonism. J Biologic Chemis. 2002; 277(39), 36040-4.

[66] Gönder M, Sanlıer N. Kahve Tüketimi ve Nörodejeneratif Hastalıklarla İlişkisi. Türkiye Klinikleri J Neur. 2014; 9(2), 67-72.
[67] Mahomoodally MF, Dursun PD, Venugopala KN. Collinsonia canadensis L. In Naturally Occurring Chemicals Against Alzheimer's Disease. Academic Press. 2021; p. 373-7.

[68] Balkrishna A, Thakur P, Varshney A. Phytochemical profile, pharmacological attributes and medicinal properties of convolvulus prostratusA cognitive enhancer herb for the management of neurodegenerative etiologies. Front Pharmacol. 2020; $11,171$.

[69] Finley JW, Gao SA. A perspective on Crocus sativus L. (Saffron) constituent crocin: a potent water-soluble antioxidant and potential therapy for Alzheimer's disease. J AgricFood Chem. 2017; 65(5), 1005-20.

[70] Ojha RP, Rastogi M, Devi BP, Agrawal A, Dubey GP. Neuroprotective effect of curcuminoids against inflammation-mediated dopaminergic neurodegeneration in the MPTP model of Parkinson's disease. J Neuroimmune Pharmacol. 2012; 7(3), 609-18.

[71] Yuliani S, Mustofa, Partadiredja G. The neuroprotective effects of an ethanolic turmeric (Curcuma longa L.) extract against trimethyltininduced oxidative stress in rats. Nutr Neurosci. 2019; 22(11), 797-804

[72] Rashed A, Abd Rahman AZ, Rathi DNG. Essential oils as a potential Neuroprotective remedy for agerelated neurodegenerative diseases: A review. Molecules. 2021; 26(4), 1107.

[73] Klemow KM, Bartlow A, Crawford J, Kocher N, Shah J, Ritsick M. Medical attributes of St. John's wort (Hypericum perforatum). Herbal medicine: biomolecular and clinical aspect. CRC Press. 2011; p. 211-37.

[74] Guo SS, Gao XF, Gu YR, Wan ZX, Lu A, Qin ZH, Luo L. Preservation of cognitive function by Lepidium meyenii (maca) is associated with improvement of mitochondrial activity and upregulation of autophagy-related proteins in middle-aged mouse cortex. Evid Based Complementary Altern Med. 2016; 1-9.

[75] Chang RCC, So KF. Use of anti-aging herbal medicine, Lycium barbarum, against agingassociated diseases. What do we know so far. Cell Mol Neurobiol. 2008; 28(5), 643-52.

[76] Chandrashekhar VM, Ranpariya VL, Ganapaty S, Parashar A, Muchandi AA. Neuroprotective activity of Matricaria recutita Linn against global model of ischemia in rats. J Ethnopharmacol. 2010; 127(3), 645-51.

[77] Kuk EB, Jo AR, Oh SI, Sohn HS, Seong SH, Roy A, Jung HA. Anti-Alzheimer's disease activity of compounds from the root bark of Morus alba L. Arch Pharm Res. 2017; 40(3), 338-49.

[78] Javidi S, Razavi BM, Hosseinzadeh H. A review of neuropharmacology effects of Nigella sativa and its main component, thymoquinone. Phytother Res. 2016; 30(8), 1219-29.

[79] Prinsloo D, Van Dyk S, Petzer A, Petzer JP. Monoamine oxidase inhibition by kavalactones from kava (piper methysticum). Planta Med. 2019; 85(14/15), 1136-42. 
[80] Jang JY, Kim HN, Kim YR, Choi YW, Choi YH, Lee JH, Choi BT. Hexane extract from Polygonum multiflorum attenuates glutamate-induced apoptosis in primary cultured cortical neurons. J Ethnopharmacol. 2013; 145(1), 261-8.

[81] Lin CM, Lin RD, Chen ST, Lin YP, Chiu WT, Lin JW, Lee MH. Neurocytoprotective effects of the bioactive constituents of Pueraria thomsonii in 6hydroxydopamine (6-OHDA)-treated nerve growth factor (NGF)-differentiated PC12 cells. Phytochem. 2010; 71(17-18), 2147-56.

[82] Park SE, Kim S, Sapkota K, Kim SJ. Neuroprotective effect of Rosmarinus officinalis extract on human dopaminergic cell line, SHSY5Y. Cell Mol Neurobiol. 2010; 30(5), 759-67

[83] Alvi SS, Ahmad P, Ishrat M, Iqbal D, Khan MS. Secondary metabolites from rosemary (Rosmarinus officinalis L.). Structure, biochemistry and therapeutic implications against neurodegenerative diseases. Natural Bio-active Compounds. Springer, Sigapure. 2019; 1-24.

[84] Sancheti S, Um BH, Seo SY. 1, 2, 3, 4, 6-penta-Ogalloyl- $\beta$-D-glucose: A cholinesterase inhibitor from Terminalia chebula. S Afr J Bot. 2010; 76(2), 285-8.

[85] Li J, Hao J. Treatment of neurodegenerative diseases with bioactive components of Tripterygium wilfordii. Am J Chin Med. 2019; 47(04), 769-85.

[86] Liu Y, Chen HL, Yang G. Extract of Tripterygium wilfordii Hook $F$ protect dopaminergic neurons against lipopolysaccharide-induced inflammatory damage. Am J Chin Med. 2010; 38(04), 801-14

[87] Shin SJ, Jeong Y, Jeon SG, Kim S, Lee SK, Choi HS, Moon M. Uncaria rhynchophylla ameliorates amyloid beta deposition and amyloid beta-mediated pathology in 5XFAD mice. Neurochem Int. 2018; 121, 114-24.

[88] Rapaka D, Bitra VR, Vishala TC, Akula A. Vitis vinifera acts as anti-Alzheimer's agent by modulating biochemical parameters implicated in cognition and memory. J Ayurveda Integr Med. 2019;10(4),241-7.

[89] Fouad GI, Rizk MZ. Possible neuromodulating role of different grape (Vitis vinifera L.) derived polyphenols against Alzheimer's dementia: treatment and mechanisms. Bull Natl Res Cent. 2019;43(1),1-13.

[90] Dar NJ. Neurodegenerative diseases and Withania somnifera (L.): An update. J Ethnopharmacol. 2020;256,112769.

[91] Talebi M, Ilgün S, Ebrahimi V, Talebi M, Farkhondeh T, Ebrahimi H, Samarghandian S. Zingiber officinale ameliorates Alzheimer's disease and cognitive impairments: lessons from preclinical studies. Biomed Pharmacother. 2021; 133, 111088.

[92] Adalı A, Yirün A, Koçer-Gümüşel B, Erkekoğlu P. Alzheimer Hastalığının Gelişiminde Biyolojik Ajanların Olası Etkileri. J Fac Pharm Ankara. 2020;44(1),167-87. 